\title{
Relacje z rówieśnikami i ich znaczenie dla młodzieży z umiarkowanym i znacznym stopniem niepełnosprawności intelektualnej w edukacji specjalnej - w świetle badań własnych
}

\begin{abstract}
Anna Drozdowicz, Relacje z rówieśnikami i ich znaczenie dla młodzieży $z$ umiarkowanym $i$ znacznym stopniem niepetnosprawności intelektualnej w edukacji specjalnej - w świetle badań własnych [Peer relationships among the young with moderate and severe intellectual disability in special education]. Interdyscyplinarne Konteksty Pedagogiki Specjalnej, nr 11, Poznań 2015. Pp. 35-54. Adam Mickiewicz University Press. ISSN 2300-391X
\end{abstract}

The article presents a summary of the research about peer relationships among the young with intellectual disability in special education classes. The studies took into consideration a) the types of the relationships and their qualitative characteristics, b) factors determining the type of the relationship, c) an individual perspective of a young disabled person in the group of mentally disabled peers.71 pupils with moderate and severe intellectual disability in 15 special education classes were observed in natural school situations. The results show a great need and abilities to participate in peer relationships by intellectually disabled teenagers. The second part of the study was based on the qualitative research procedure and revealed different subjective meaning of participation of 7 young intellectually disabled students in the school peer group. Findings of the study gave practical indications for arranging special classes of pupils with moderate and severe intellectual disability. Results was discussed with current tendency to inclusive education people with disability.

KEY WORDS: peer relationships, moderate and severe intellectual disability, special and inclusive education 
Uczestniczenie przez dzieci i młodzież z umiarkowanym i znacznym stopniem niepełnosprawności intelektualnej w klasowym systemie nauczania daje im możliwość częstego przebywania w gronie rówieśników, a przez to stwarza szansę na nawiązywanie z nimi bezpośrednich stosunków. Zagadnienie wzajemnych relacji młodzieży z głębszą niepełnosprawnością intelektualną w placówkach specjalnych było przedmiotem dociekań badawczych w niewielkim tylko stopniu1. Dużo większe zainteresowanie badaczy kierowane było $\mathrm{w}$ stronę relacji rówieśniczych $\mathrm{w}$ układzie integracyjnym. Badania z tego zakresu dotyczą jednak przede wszystkim osób z lekkim stopniem niepełnosprawności intelektualnej, nastawień sprawnych rówieśników do niepełnosprawnych kolegów i koleżanek czy relacji między sprawnym i niepełnosprawnym rodzeństwem². Na polskim gruncie widoczny jest brak doniesień z badań na temat rówieśniczych relacji interpersonalnych w szkole specjalnej dla osób z umiarkowanym i znacznym stopniem niepełnoprawności intelektualnej.

Kim są dla dorastającej osoby z głębszą niepełnosprawnością intelektualną jej również niepełnosprawni intelektualnie klasowi koledzy i koleżanki? Jaki jest rodzaj i jakość tworzonych przez nich

${ }^{1}$ Najbardziej rozbudowane badania interakcji osób z umiarkowanym stopniem niepełnosprawności $w$ wieku 12-21 lat przebywających w Specjalnym Zakładzie Wychowawczym przeprowadził Z Bartkowicz, Struktura i niektóre uwarunkowania interakcji przejawianych przez upośledzonych umystowo w stopniu umiarkowanym $i$ znacznym, [w:] Optymalizacja interakcji w procesie usprawniania osób z dysfunkcjami fizycznymi i psychicznymi, red. S. Kowalik, J. Kwiek, B. Szychowiak, Wydawnictwo Naukowe UAM, Poznań 1989. Problematykę relacji uczuciowych badała I. Fornalik, Rozwój psychoseksualny młodzieży z głębsza niepetnosprawnościa intelektualna w zależności od środowiska życia, nie publikowana praca doktorska, UAM, Poznań 2002. Światło na specyfikę relacji rówieśniczych osób z niepełnosprawnością intelektualną rzuciły także badania B. Górnickiej, Plany życiowe młodzieży z lekkim upośledzeniem umystowym, Uniwersytet Opolski, Opole 2004.

2 Przykładowe opracowania to: A. Maciarz, Z teorii i badań społecznej integracji dzieci niepetnosprawnych, Oficyna Wydawnicza „Impuls”, Kraków 1999; Integracja społeczna osób niepetnosprawnych, red. G. Dryżałowska, H. Żuraw, Żak, Warszawa 2004; A. Żyta, Rodzeństwo osób z głębsza niepetnosprawnościa intelektualna, Impuls, Kraków 2004, s. 164. 
relacji? Powyższe pytania były inspiracją do podjęcia rozległych badań empirycznych, których podsumowanie pragnę przedstawić w poniższym artykule 3 . Pomimo upływu czasu, jaki minął od przeprowadzenia badań, myślę, że warto je przywołać i skonfrontować $\mathrm{z}$ aktualną tendencją do promowania edukacji włączającej uczniów z głębszą niepełnosprawnością intelektualną4.

\section{Metodologiczne podstawy badań i ich przebieg}

Kierunek pracy badawczej wyznaczały trzy cele naukowo-poznawcze: 1) poznanie i scharakteryzowanie, jakiego rodzaju stosunki interpersonalne tworzy młodzież z głębszą niepełnosprawnością intelektualną ze swymi niepełnosprawnymi intelektualnie rówieśnikami w klasach szkół specjalnych; 2) poznanie czynników, które mogą być szczególnie istotne dla kształtowania wyróżnionych stosunków; 3) hermeneutyczne zrozumienie znaczeń, jakie mają dla danej młodzieży relacje z jej szkolnymi rówieśnikami. Ze względu na cel i przedmiot badań została przyjęta strategia badań ilościowo-jakościowych, a ich przebieg zaplanowano w dwóch etapach. Etap I (realizacja celu 1. i 2.) miał charakter diagnostyczny i pozwolił na ujrzenie badanego zjawiska w szerokiej skali, jakby „z lotu ptaka”. Etap II (realizacja celu 3.) ukierunkowany był na poznanie zjawiska w perspektywie jednostkowej (swoiste „zbliżenie lupy”) w oparciu o metodę studium przypadków.

Głównym przedmiotem badań były relacje rówieśnicze, które (jak wszystkie relacje międzyludzkie) są niezwykle złożonym fenomenem rzeczywistości, a przez to trudnym do gruntownego

${ }^{3}$ A. Drozdowicz, Stosunki rówieśnicze młodzieży z umiarkowana i znaczna niepetnosprawnościa intelektualnq w klasach szkolnictwa specjalnego, niepublikowana praca doktorska, UAM, Poznań 2007.

${ }^{4}$ Konwencja o prawach osób niepetnosprawnych, (Dz.U. z 2012 r., poz. 1169), zobowiązuje Państwa Strony do zapewnienia edukacji włączającej osobom niepełnosprawnym. 
zbadania. Zdefiniować je można jako trwałe oddziaływanie na siebie osób, które odbywa się na powiązanych ze sobą płaszczyznach behawioralnej i psychicznej (schemat 1$)^{5}$.

\section{RELACJA INTERPERSONALNA}

Trwałe oddziaływanie na siebie osób, które odbywa się na powiązanych ze sobą płaszczyznach behawioralnej i psychicznej

\begin{tabular}{|c|c|c|}
\hline $\begin{array}{c}\text { płaszczyzna behawioralna } \\
\text { względnie trwały wzorzec interakcji } \\
\text { podejmowanych przez dwie osoby } \\
\text { wypracowany w wyniku wielo- } \\
\text { krotnych kontaktów }\end{array}$ & $\begin{array}{c}\text { płaszczyzna psychiczna } \\
\text { schemat poznawczo-emocjonalny } \\
\text { obejmujący obraz i ocenę: } \\
\text { a) partnera, b) siebie w odniesieniu } \\
\text { do partnera i c) wzajemnych interakcji }\end{array}$ \\
\hline
\end{tabular}

Schemat 1. Definicja pojęcia relacja interpersonalna

Badania empiryczne najczęściej bazują na wypowiedziach badanych, ich deklaracjach dotyczących odniesień do innych osób, a zatem bazują na płaszczyźnie psychicznej badanych relacji. W przypadku młodzieży z głębszą niepełnosprawnością intelektualną tego typu badania byłyby dość ubogie albo w ogóle niemożliwe do przeprowadzenia ze względu na sprawność umysłową i możliwości językowe tych młodych ludzi. W związku z tym badania relacji oparłam przede wszystkim na płaszczyźnie behawioralnej relacji, a zatem na obserwacji wzajemnych interakcji i określeniu względnie trwałego wzorca interakcji ukształtowanego podczas wielokrotnych kontaktów. Ideę metody badawczej oraz wymiary obserwacji i analizy materiału obrazuje schemat 2 .

${ }^{5}$ Definicja relacji interpersonalnej została opracowana na podstawie: Z. Zaborowski Z., Stosunki międzyludzkie, Ossolineum, Wrocław 1976; R.A. Hinde, J. Stevenson-Hinde, Związki interpersonalne a rozwój dziecka, [w:] Dziecko w świecie ludzi i przedmiotów, red. A. Brzezińska, G. Lutomski, Zysk S-ka, Poznań, 1994, s. 47-63; por. R.B. Adler, L.B. Rosenfeld, R.F. Proctor II, Relacje interpersonalne, Rebis, Poznań 2006. 


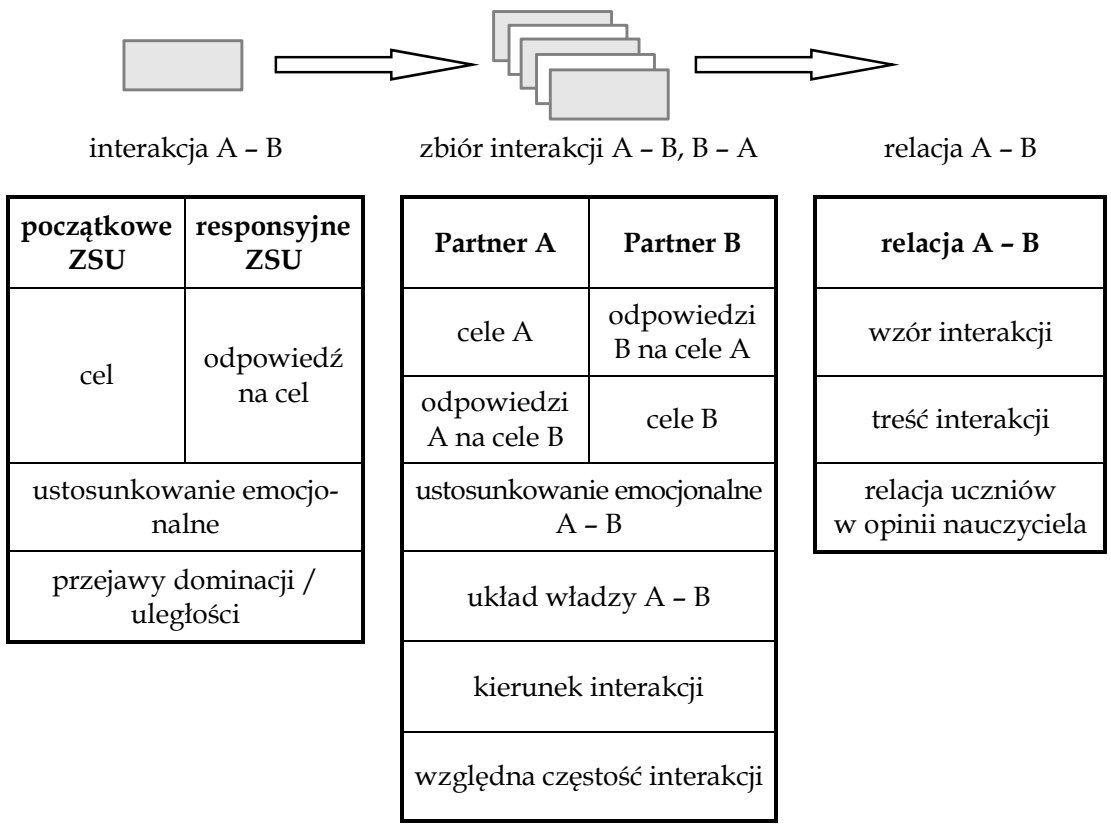

Schemat 2. Wymiary obserwacji i analiza materiału badawczego

Kluczowym wymiarem analizy zaobserwowanych interakcji były cele początkowych zachowań społecznie ukierunkowanych (ZSU), czyli zachowań inicjujących interakcję w diadzie. Cele rozumiane były jako realizacja intencji, jako efekt, który został zrealizowany przez ZSU lub do którego realizacji ZSU zmierzało w odniesieniu do partnera kontaktu' ${ }^{6}$ W wyniku analizy indukcyjnej początkowych ZSU wyodrębniono dziewięć kategorii celów tychże zachowań. Są to następujące cele: informacyjny (eksploracyjny), ekspresyjny,

${ }^{6}$ Powyższe podejście zostało oparte na teorii aktów mowy J. Austina i J. Searla (por. R. Grzegorczykowa, Wprowadzenie do semantyki jezykoznawczej, PWN, Warszawa 2002, I. Kurcz, Psychologia jezzyka i komunikacji, Scholar, Warszawa 2000), która zakłada, że za treścią wypowiedzi kryje się głębsza warstwa zachowaniakomunikatu związana z tym, co nadawca chce w stosunku do drugiej osoby uczynić lub osiągnąć. 
wspólnotowy, dobroczynny, regulacyjny pośredni motywujący, regulacyjny bezpośredni, przedmiotowy, krzywdzący i formalny. Analiza zachowań interakcyjnych dotyczyła ponadto ustosunkowania emocjonalnego partnerów względem siebie oraz przejawów dominacji lub uległości jednego ucznia wobec drugiego.

Kolejny poziom analizy dotyczył zbioru interakcji nawiązywanych w diadzie uczniów A i B. Oprócz uogólnienia wyżej opisanych wymiarów, określał on także dominujący kierunek interakcji, oceniając, czy uczniowie w równym stopniu inicjują wzajemny kontakt oraz jak często nawiązywane są przez nich swobodne kontakty. Wzór interakcji każdej diady był następnie wzbogacany o analizę treści interakcji i konfrontowany z opinią nauczyciela. Tak stworzone charakterystyki relacji rówieśniczych stanowiły materiał do dalszej analizy wyników badań.

W przypadku 1. i 3. celu badań nie formułowano hipotez badawczych, gdyż dotyczyły one badań diagnostycznych i miały w dużej mierze charakter jakościowy. Uzyskanie odpowiedzi na pytanie o rodzaje badanych relacji rówieśniczych (cel 1) doprowadziła do wysunięcia hipotez co do czynników istotnych dla kształtowania wyróżnionych stosunków, a w szczególności w odniesieniu do zależności między typami stosunków rówieśniczych badanej młodzieży a takimi zmiennymi niezależnymi jak: poziom funkcjonowania intelektualnego, poziom czynności samoobsługowych i obecność zaburzeń zachowania uczestników relacji oraz braku zależności pomiędzy typem relacji a poziomem umiejętności werbalnych uczniów.

Wiodącą metodą badawczą w prezentowanych badaniach była obserwacja uczestnicząca, która na I etapie trwała średnio 4-5 dni, a na II etapie - ok. 3-4 tygodnie w jednej klasie. Innymi metodami gromadzenia materiału badawczego były: swobodny wywiad z uczniem, ukierunkowany wywiad z nauczycielem i z rodzicem, analiza rysunku pt. „Moja klasa” oraz analiza dokumentów.

Badania zostały przeprowadzone w poznańskich szkołach specjalnych wśród młodzieży w wieku od 12. do 22. roku życia. W I etapie badań uczestniczyło 71 uczniów z 15 klas z poziomu 
szkoły podstawowej, gimnazjum i szkoły przysposabiającej do pracy (tab. 1). Na podstawie uzyskanych wyników do II etapu badań wybrano 7 uczniów (3 dziewcząt i 4 chłopców) z 3 klas po 1 z każdego poziomu edukacyjnego.

Tabela 1. Uczestnicy badań

\begin{tabular}{|l|c|c|c|c|c|c|c|c|}
\hline \multirow{2}{*}{$\begin{array}{c}\text { Poziom } \\
\text { nauczania }\end{array}$} & $\begin{array}{c}\text { Liczba } \\
\text { klas }\end{array}$ & $\begin{array}{c}\text { Liczba } \\
\text { uczniów }\end{array}$ & $\begin{array}{c}\text { Liczba } \\
\text { dziewcząt }\end{array}$ & $\begin{array}{c}\text { Liczba } \\
\text { chłopców }\end{array}$ & $\mathrm{Um}^{*}$ & $\mathrm{Zn}^{*}$ & \multicolumn{2}{|c|}{ Wiek uczniów } \\
\hline Szkoła podstawowa & 3 & 15 & 7 & 8 & 12 & 3 & 12 & 3 \\
\hline Gimnazjum & 9 & 40 & 20 & 20 & 24 & 16 & 15 & 25 \\
\hline $\begin{array}{l}\text { Szkoła przyspobie- } \\
\text { nia do pracy }\end{array}$ & 3 & 16 & 9 & 7 & 16 & 0 & 0 & 16 \\
\hline RAZEM & 15 & 71 & 36 & 35 & 52 & 19 & 27 & 44 \\
\hline
\end{tabular}

* Liczba uczniów niepełnosprawnych intelektualnie w stopniu umiarkowanym (um.) lub znacznym (zn); stopień niepełnosprawności określony na postawie orzeczeń poradni psychologiczno-pedagogicznej

\section{Wyniki badań}

\section{Rodzaje relacji rówieśniczych}

I etap badań pokazał, że prawie wszyscy badani (69osób) brało czynny udział $\mathrm{w}$ kształtowaniu relacji z rówieśnikami tworząc między sobą $72 \%$ możliwych diadycznych układów interakcyjnych. Dzięki zaangażowaniu wyszkolonych obserwatorów udało się zebrać obszerny materiał badawczy. Analizie poddano łącznie 2023 zarejestrowane interakcje, na podstawie których stworzono charakterystyki 103 relacji rówieśniczych badanej młodzieży. Wśród nich wyróżniono 19 jakościowo odmiennych typów stosunków interpersonalnych, które zostały opisane w 4 grupach relacji odpowiednio do przeważającego $\mathrm{w}$ nich ustosunkowania emocjonalnego: pozytywnego (52\% zaobserwowanych relacji), negatywnego (19\%), obojętnego (15\%) i ambiwalentnego (14\%). 
Najliczniejszą grupę relacji tworzyły stosunki o przewadze pozytywnych ustosunkowań emocjonalnych 7 . Brało w nich udział 54 uczniów, co stanowi 76\% grupy badawczej. Relacje pozytywne pełne cechowały się wzajemnością i silnym zaangażowaniem obu partnerów. W ich intensywnych i częstych kontaktach dominowały zachowania wspólnotowe i ekspresyjne polegające na wspólnym działaniu oraz wyrażaniu swoich myśli, uczuć i przeżyć wobec rówieśnika. We wszystkich tych relacjach uczniowie byli dla siebie ważni, wysoko cenili siebie nawzajem, budowali pozytywne obrazy siebie i partnera. Jednocześnie kształtowało się u nich poczucie przynależności i „posiadania” kolegi, sympatii czy przyjaciela.

Dużo większą grupę tworzyły relacje pozytywne niepełne, w których uczestniczyło łącznie 44 uczniów (62\% grupy badawczej). $\mathrm{W}$ relacjach pozytywnych niepełnych brakowało równego zaangażowania obu stron kontaktów lub wzajemne odniesienia były słabe, a częstość kontaktów mała. Na płaszczyźnie behawioralnej stosunków pozytywnych niepełnych występowała przewaga zachowań wspólnotowych i ekspresyjnych, które często były odrzucane lub pozostawiane bez odpowiedzi rówieśnika. $W$ części relacji dochodziło do prób dominacji jednego ucznia nad drugim oraz pojawiania się ze strony partnera silniej dążącego do wzajemności zachowań dobroczynnych i informacyjnych będących swoistym ekwiwalentem oczekiwanej życzliwości kolegi lub koleżanki. Pod względem psychicznej płaszczyzny stosunku interpersonalnego charakterystyczną cechą relacji pozytywnych niepełnych były różnice we wzajemnej ocenie wartości partnerów, którzy w nierównym stopniu byli zaangażowani $w$ tworzoną relację. Szczegółowa analiza zachowań uczniów wskazała na różne bariery na drodze do wzajemności. Wśród nich należy wymienić: różnicę pozycji uczniów w klasie, przejawy infantylizmu, dążenie do dominacji jednej ze stron czy

7 Wśród relacji pozytywnych wyróżniono dwie podgrupy: stosunki pozytywne pełne (16 diad: wzajemne koleżeństwo - 9 diad, przyjaźń - 4, sympatia odwzajemniona - 3) i pozytywne niepełne (38 diad: pozytywne nastawienie - 14 diad, nierówne koleżeństwo - 8, dążenie do wzajemności - 7, sympatia nieodwzajemniona - 5, koleżeństwo z walorem kontroli - 4). 
niespełnianie przez partnera pewnych oczekiwań przy braku innych korzystniejszych alternatyw interpersonalnych w klasie. Relacje pozytywne niepełne w szczególny sposób pokazują istniejącą wśród badanej młodzieży potrzebę tworzenia wzajemnie pozytywnych stosunków rówieśniczych, unaoczniając przy tym liczne trudności, które dane osoby napotykają w realizacji tego celu.

Kolejną co do wielkości grupą relacji rówieśniczych były stosunki o przewadze negatywnych ustosunkowań emocjonalnych $(20 \mathrm{diad})^{8}$. Zasadniczą cechą relacji negatywnych było wyrażanie wobec rówieśnika swojej niechęci czy wręcz awersji, następnie wydawanie mu poleceń, poganianie, upominanie, a w skrajnych przypadkach dążenie do wyrządzenia mu krzywdy. Kolejną cechą było unikanie interakcji typu wspólnotowego. Przyczyn niechęci do klasowego rówieśnika należy upatrywać w postrzeganiu go jako odmieńca czy upośledzonego, w braku akceptacji jego osoby, jego sposobu funkcjonowania lub też $\mathrm{w}$ niezgadzaniu się na jego określone zachowania interakcyjne kierowane do danego ucznia. Grupę rówieśników nielubianych stanowiło 15 osób, w tym 4 z nich nie uczestniczyło $\mathrm{w}$ żadnej relacji pozytywnej z innym uczniem w klasie. Zajmowali oni zazwyczaj pozycję ucznia najsłabszego lub przeciętnego. Większość z nich przejawiała zaburzenia zachowania.

Powyższe wyniki badań wskazują na trudną sytuację zarówno osób dotkniętych zaburzeniami zachowania wywołującymi awersję, jak i młodzieży przebywającej $\mathrm{w}$ obecności takich rówieśników. Wyrazy negatywnych emocji wobec niepełnosprawnych kolegów/koleżanek można uznać za przejaw trudności radzenia sobie z sytuacją dostrzegania ich odmienności. Ponadto warto zwrócić uwagę na fakt, że 17 spośród 20 omawianych relacji cechowało się negatywnym ustosunkowaniem jednostronnym. Oznacza to, że nielubiany rówieśnik przyjmował zachowania awersyjnego kolegi w sposób bierny lub próbował pomimo wszystko nawiązywać

${ }^{8}$ Były to relacje o ustosunkowaniach negatywnych jednostronnych (niechęć 9 diad, odrzucanie -5 , awersja -3 ) i negatywnych dwustronnych (strach -2 diady, wrogość - 1). 
z nim pozytywne kontakty. Powyższa sytuacja nasuwa wniosek o ważności kontaktów rówieśniczych dla osób z głębszą niepełnosprawnością intelektualną, którzy pomimo płacenia dużych kosztów związanych $\mathrm{z}$ niechęcią klasowego rówieśnika, nie rezygnują wobec niego z prób nawiązywania pozytywnych interakcji i uzyskania jego życzliwości.

Relacje o przewadze obojętnych ustosunkowań emocjonalnych (15 relacji $)^{9}$ charakteryzowały się przewagą diad jednostronnych. Dominowały $w$ nich inicjujące zachowania regulacyjne bezpośrednie i dobroczynne. Brak wyraźnych przejawów życzliwości czy niechęci do rówieśnika wskazuje, że istotnym elementem uczestnictwa w tego typu relacjach była sama aktywność ucznia A, który mógł kierować, opiekować się lub czynić coś dobrego dla innego mniej sprawnego ucznia. Wyjątkiem były relacje dobroczynne, w których uczeń A dążył do uzyskania życzliwości i wzajemności kolegi/koleżanki poprzez świadczenie mu różnych przysług.

Obecność powyższej sytuacji wskazuje na postrzeganie mniej sprawnych rówieśników jako tych, którymi trzeba kierować, pomagać, a nie jako potencjalnych partnerów relacji koleżeńskich i przyjacielskich. Uczniowie przejawiając zachowania typowe dla kontaktów z osobami niepełnosprawnymi, jak kierowanie i opieka, niejako stawiają siebie po stronie ludzi sprawnych. Partnerzy poddający się kierowaniu rówieśników w zasadzie realizują schemat, jakiego doświadczają w kontaktach z dorosłymi: posłusznego wykonywania poleceń i oczekiwania pomocy. Analiza jakościowa, oprócz pokazania możliwości działań altruistycznych ze strony młodzieży z umiarkowaną niepełnosprawnością intelektualną, sygnalizuje potencjalne zagrożenie nadużyć i niewłaściwego traktowania mniej sprawnych rówieśników.

Do ostatniej grupy ambiwalentnych relacji rówieśniczych (15 diad) zaliczono 3 typy stosunków: zrealizowane dążenie do podporządkowania - 6 diad, koleżeństwo ambiwalentne - 5 i utrudnio-

${ }^{9}$ Były to relacje dobroczynne - 6 diad, kierownicze - 5 i kierowniczo-opiekuńcze -4 . 
ne dążenie do podporządkowania - 3. Główną cechą tego typu stosunków rówieśniczych było przejawianie przez ucznia A o ambiwalentnym ustosunkowaniu emocjonalnym sprzecznych tendencji dążenia do pozytywnego kontaktu z rówieśnikiem (przyciąganie) oraz wyrażanie złości, negatywnej oceny jego osoby (odpychanie) lub dążenie do zdobycia nad nim władzy (podporządkowanie).

Ustosunkowania ambiwalentne przejawiali głównie uczniowie o najwyższym poziomie funkcjonowania intelektualnego w zakresie niepełnosprawności intelektualnej umiarkowanego stopnia w wieku powyżej 16 lat (okres późnej adolescencji). Wyniki badań wskazują na pojawiający się $\mathrm{u}$ nich konflikt związany $\mathrm{z}$ poziomem ich samoświadomości oraz postrzeganiem odmienności niepełnosprawnych rówieśników, niespełniania przez nich określonych wymogów „normalności”. Uczeń B nie był idealnym partnerem, ale w największym stopniu spośród uczniów w klasie spełniał poziom oczekiwań ucznia A. Powołując się na teorię wymiany społecznej10, można powiedzieć, że uczeń B plasował się poniżej poziomu porównań, ale niski poziom alternatyw sprawiał, że kontakty z nim niosły określoną wartość dla ucznia A.

\section{Czynniki istotne dla kształtowania relacji rówieśniczych}

Dla potrzeb analiz statystycznych przyjęto dwojaki podział typów badanych relacji: a) ze względu na dominujące ustosunkowanie emocjonalne oraz b) układ władzy w diadzie. Poszczególnym zmiennym niezależnym przypisano zmienne szczegółowe odnoszące się do obu partnerów relacji (A i B) oraz układu wartości zmiennych między nimi (różnica A - B). Ze względu na to, że większość danych miała charakter nominalny do analiz statystycznych, zastosowano test niezależności Chi-kwadrat Pearsona.

Wyniki analiz potwierdziły hipotezę co do całkowitego brak związku między poziomem umiejętności werbalnych a typami rela-

${ }^{10}$ R. Cialdini, Wywieranie wptywu na ludzi. Teoria i praktyka, GWP, Gdańsk 2011. 
cji rówieśniczych. Związek między pozostałymi zmiennymi niezależnymi został potwierdzony tylko częściowo. Zależności istotne statystycznie prezentuje tabela 2 .

Poziom funkcjonowania intelektualnego partnera A różnicował relacje pod względem dominującego ustosunkowania emocjonalnego w diadzie. Wyniki wskazują na granicę, która w tym względzie przebiega mniej więcej między znacznym i umiarkowanym stopieniem niepełnosprawności intelektualnej. Mniej sprawni uczniowie przejawiają mniejszą i mniej zróżnicowaną aktywność interpersonalną, dążąc głównie do relacji pozytywnych, a uczniowie sprawniejsi prezentują bogatszy zbiór aktywizowanych stosunków rówieśniczych.

Tabela 2. Zależności istotne statystycznie między wyróżnionymi zmiennymi

\begin{tabular}{|c|c|c|c|}
\hline \multicolumn{2}{|c|}{ Zmienna niezależna } & \multicolumn{2}{|c|}{ Typ relacji wyróżniony ze względu na: } \\
\hline główna & szczegółowa & $\begin{array}{l}\text { ustosunkowanie emo- } \\
\text { cjonalne w diadzie }\end{array}$ & $\begin{array}{c}\text { układ władzy } \\
\text { w diadzie }\end{array}$ \\
\hline \multirow{5}{*}{$\begin{array}{l}\text { Poziom } \\
\text { funkcjonowa- } \\
\text { nia intelektu- } \\
\text { alnego }\end{array}$} & uczeń A & $\begin{array}{l}\operatorname{tak}\left(\chi^{2}=29,50261\right. \\
\mathrm{df}=16, \mathrm{p}=0,021)\end{array}$ & - \\
\hline & uczeń B & - & - \\
\hline & różnica A - B & - & $\begin{array}{c}\operatorname{tak}\left(\chi^{2}=14,08366 ; d f=2\right. \\
p=0,001)\end{array}$ \\
\hline & $\begin{array}{l}\text { status A } \\
\text { w klasie }\end{array}$ & $\begin{array}{c}\text { tak }\left(X^{2}=19,33829 ; d f=8\right. \\
p=0,013)\end{array}$ & - \\
\hline & $\begin{array}{l}\text { status B } \\
\text { w klasie }\end{array}$ & $\begin{array}{c}\text { tak }\left(X^{2}=24,96636 ; d f=8,\right. \\
p=0,002)\end{array}$ & $\begin{array}{c}\operatorname{tak}\left(\chi^{2}=19,27597 ; d f=2\right. \\
p=0,000)\end{array}$ \\
\hline \multirow{3}{*}{$\begin{array}{l}\text { Poziom czyn- } \\
\text { ności samoob- } \\
\text { sługowych }\end{array}$} & uczeń A & - & - \\
\hline & uczeń B & $\begin{array}{l}\text { tak }\left(\chi^{2}=29,28865\right. \\
d f=12, p=0,004)\end{array}$ & - \\
\hline & różnica A - B & $\begin{array}{c}\operatorname{tak}\left(\chi^{2}=29,00637 ; d f=8\right. \\
p=0,000)\end{array}$ & $\begin{array}{c}\text { tak }\left(\chi^{2}=6,899665 ; d f=2,\right. \\
p=0,032)\end{array}$ \\
\hline \multirow{2}{*}{$\begin{array}{l}\text { Obecność } \\
\text { zaburzeń } \\
\text { zachowania }\end{array}$} & uczeń A & - & - \\
\hline & uczeń B & $\begin{array}{c}\text { tak }\left(X^{2}=23,85579 ; d f=4\right. \\
p=0,000)\end{array}$ & $\begin{array}{c}\text { tak }\left(\chi^{2}=10,932 ; d f=1\right. \\
p=0,001)\end{array}$ \\
\hline
\end{tabular}

A, B - uczestnicy relacji; partnerem A był określany uczeń, który inicjował więcej interakcji w diadzie 
Ważną zmienną okazał się statusu ucznia w klasie (określenie poziomu funkcjonowania ucznia na tle grupy klasowej) ${ }^{11}$. Najmniej korzystna pod względem ustosunkowań emocjonalnych i podziału władzy w diadzie jest pozycja najsłabszego ucznia w klasie. Narażony on jest w największym stopniu na negatywne ustosunkowanie innych uczniów, na traktowanie go przez nich w sposób kierowniczy i zajmowanie $\mathrm{w}$ relacjach pozycji podporządkowanej. Uczeń najsłabszy ma najmniejsze szanse na zyskanie życzliwości sprawniejszych rówieśników oraz na stworzenie w pełni pozytywnych relacji interpersonalnych. Uczniowie najlepsi byli najczęstszymi odbiorcami ustosunkowań pozytywnych, ale też najczęstszymi uczestnikami relacji ambiwalentnych. Tylko w sporadycznych przypadkach byli traktowani w sposób dominujący przez swoich klasowych rówieśników.

Powyższe wyniki wskazują na ważność doboru uczniów do zespołu klasowego. Należy przypuszczać, że ten sam uczeń w dwóch różnych pod względem składu osobowego grupach będzie inicjował, ale także będzie odbiorcą jakościowo różnych relacji rówieśniczych.

Zależność istotna statystycznie istniała między typami stosunków skategoryzowanymi ze względu na ustosunkowanie emocjonalne oraz układ władzy w diadzie a różnicą poziomów samoobsługi uczestników relacji oraz poziomem samoobsługi i obecnością zaburzeń zachowania ucznia B. Uczniowie całkowicie uzależnieni w samoobsłudze od pomocy innych oraz przejawiający zaburzenia zachowania wyzwalali wśród swych bardziej sprawnych rówieśników ustosunkowania negatywne, zachowania kierownicze, opiekuńcze oraz zajmowanie wobec nich nadrzędnej pozycji w układzie interakcyjnym. Obok tego relacje pozytywne pełne tworzyli uczniowie o takim samym poziomie samoobsługi i braku zaburzeń zachowania.

11 Ważność tej zmiennej uwydatniły również badania klas integracyjnych J. Sikorski, Pozycja społeczna dziecka niepetnosprawnego w klasie integracyjnej, [w:] O poznawaniu siebie $i$ świata przez dziecko ze specjalnymi potrzebami edukacyjnymi, red. W. Pilecka, K. Bidziński, M. Pietrzkiewicz, Wydawnictwo UHP, Kielce, 2008, s. 491-496. 
Zestawienie powyższych wyników nasuwa wniosek o ważności obserwowalnych cech partnera B, które można określić jako zgodne lub niezgodne ze stanem „normalności”12. Przewaga zależności istotnych statystycznie dotyczących partnera B w całym zbiorze weryfikowanych związków sugeruje, że rodzaj nawiązywanej relacji jest po części odpowiedzią uczniów A na postrzegane cechy zachowania rówieśnika oraz zajmowaną przez niego pod względem funkcjonowania pozycję $\mathrm{w}$ klasie. Idąc dalej, powyższy wniosek wskazuje na ważność procesów postrzegania i wartościowania cech potencjalnego partnera relacji.

\section{Znaczenie relacji rówieśniczych}

Odpowiedź na trzecie pytanie badawcze, dotyczące subiektywnych znaczeń uczestniczenia $\mathrm{w}$ stosunkach rówieśniczych przez młodzież z głębszą niepełnosprawnością intelektualną, dostarczył II etap badań. Jego wyniki pokazują szeroki horyzont wartości i sensu wspomnianego uczestnictwa rozciągający się od czerpania pozytywnych doświadczeń z relacji ze szkolnymi kolegami/koleżankami po poczucie dyskomfortu i braku (schemat 3).

Doświadczenia kontaktów Eweliny i Kamila z grupą klasową można określić jako „bycie wśród swoich”. Ich przypadki wskazują na to, że niepełnosprawni rówieśnicy, będąc w klasie specjalnej, mogą znaleźć zrozumienie osób o podobnym sposobie widzenia świata i tworzyć swoisty rodzaj wspólnoty. Jest to świat, w którym młodzi doświadczają koleżeństwa, zakochania, w którym odgrywają ważne dla siebie role, który rozwija swoją tożsamość i niezależność.

12 Wyniki badań pokrywają się w tym względzie z badaniami A. Maciarz dotyczących relacji rówieśniczych młodzieży z niepełnosprawnością w układzie integracyjnym. Istotnym czynnikiem dla tworzonych odniesień okazał się wówczas stopień widoczności niepełnosprawności uczniów A. Maciarz, Integracja edukacyjna w świetle doświadczeń i oczekiwań dzieci niepetnosprawnych, [w:] Dziecko ze specjalnymi potrzebami edukacyjnymi w ekosystemie, red. W. Pilecka, A. Ozga, P. Kurtek, Wydawnictwo AŚ, Kielce 2005, s. 79-84. 


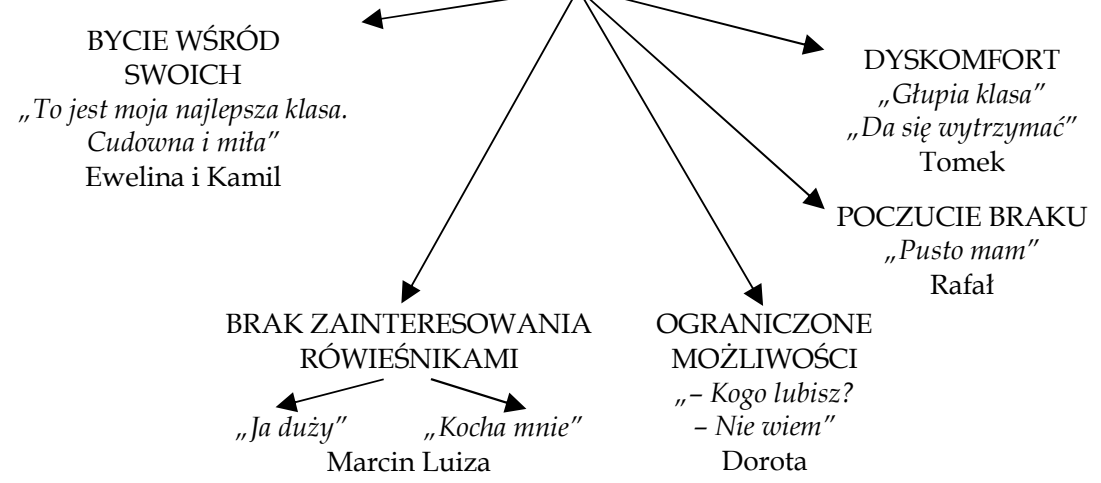

Schemat 3. Spektrum znaczeń relacji rówieśniczych dla młodzieży z umiarkowaną niepełnosprawnością intelektualną

Bycie wśród niepełnosprawnych rówieśników miało zupełnie przeciwstawne znaczenie dla Tomka. Na rysunku "Moja klasa” umieścił on swoją postać ponad grubą czarną linią oddzielającą go od mniej sprawnych, choć bardziej ze sobą zżytych pozostałych uczniów. "Głupia klasa” - jak ją Tomek określił - była miejscem, gdzie uczeń nie potrafił nawiązać żadnych wzajemnie pozytywnych relacji ani zdobyć wysokiej pozycji społecznej, pomimo iż był najsprawniejszym uczniem $\mathrm{w}$ klasie. Uczestniczenie $\mathrm{w}$ grupie rówieśników było dla niego dyskomfortem, wiązało się z doświadczaniem negatywnych emocji, frustracji i sprzecznych tendencji. Sytuację Tomka można podsumować stwierdzeniem, że był „na niewłaściwym miejscu". Odnosi się ono także do przypadku innego ucznia - Rafała, którego poczucie braku satysfakcjonujących relacji rówieśniczych było ukryte pod pozorami ogólnie panującej wzajemnej życzliwości uczniów w klasie. Dopiero bliższe poznanie ucznia ujawniło jego niezaspokojoną potrzebę posiadania bliskiego przyjaciela, z którym mógłby rozmawiać i przeżywać postępujący intensywnie $u$ niego proces dorastania.

Pomiędzy przedstawionymi znaczeniami uczestnictwa $\mathrm{w}$ relacjach rówieśniczych znajdują się inne znaczenia, których praca badawcza na pewno nie odkryła w całości. Do nich należy zaliczyć 
brak zainteresowania klasowymi rówieśnikami i poszukiwanie satysfakcjonujących kontaktów wśród osób dorosłych. W jednym $\mathrm{z}$ analizowanych przypadków zachowania takie były sposobem budowania swojej tożsamości jako osoby dorosłej. Wyrazem tego jest sposób mówienia o sobie przez Marcina: "Ja duży”, natomiast o innych uczniach „Oni dzieci”. W przypadku Luizy - kierowanie się $\mathrm{w}$ stronę nauczycieli było poszukiwaniem zainteresowania i afirmacji swojej osoby oraz zaspokojenia typowej dla okresu dzieciństwa potrzeby bycia kochanym.

Ostatni przypadek - Doroty ukazał problem ograniczeń w budowaniu relacji interpersonalnych wynikających $\mathrm{z}$ bagażu niepełnosprawności. Trudności komunikacyjne, zaburzenia zachowania, brak interpersonalnych umiejętności takich jak chociażby dzielenia się z innymi, współpracy czy werbalnego wyrażania swoich emocji - to czynniki, które utrudniały Dorocie kształtowanie pożądanych przez nią pozytywnych stosunków z rówieśnikami. Rysunek pt. "Moja klasa” przedstawiający jedną postać, zdaje się być ikoną niemożności Doroty, a zarazem pokazuje jej stan samotności. Był on udziałem uczennicy, nie $\mathrm{w}$ sensie braku fizycznego kontaktu $\mathrm{z}$ innymi ludźmi, ale w sensie swoistego "odcięcia”, "braku dostępu" do samej siebie, a przez to do innych.

\section{Wnioski - w perspektywie edukacji włączającej i edukacji specjalnej}

Wyniki badań wyraźnie dowodzą, że młodzież z umiarkowaną i znaczną niepełnosprawnością intelektualną wykazuje znaczącą wrażliwość społeczną na swych klasowych rówieśników, dąży do wzajemnych kontaktów oraz może tworzyć z nimi pozytywne stosunki rówieśnicze. Fakt, że prawie połowa zaobserwowanych relacji nie zawierała wyraźnie pozytywnych odniesień interpersonalnych, pokazuje przy tym, że sfera stosunków rówieśniczych może być dla tej młodzieży obszarem problemowym, trudnym, a nawet dyskomfortowym. Analiza relacji negatywnych, obojętnych i ambiwalentnych ukazała pro- 
blem postrzegania i uświadamiania sobie przez część młodzieży faktu niepełnosprawności klasowych kolegów i koleżanek. Wyrazem tego jest pojawianie się tendencji do dominacji i kontroli wobec uczniów mniej sprawnych oraz trudności ustosunkowywania się do osób przejawiających zaburzenia zachowania. Ponadto analiza zbiorów interakcji pokazała logiczność zachowań interpersonalnych badanej młodzieży zarówno pod względem interpretacji intencji partnera, oceny jakości tworzonej relacji, jak i rozeznania w stosunkach łączących pozostałych uczniów w klasie. Wskazuje to na lepsze operowanie informacjami płynącymi ze świata społecznego niż przedmiotowego u osób z głębszą niepełnosprawnością intelektualną. Jednocześnie zaobserwowane braki umiejętności interpersonalnych pokazują, że młodzież nie zawsze radzi sobie z wykorzystaniem informacji o innych ludziach $w$ warstwie działaniowej.

W obliczu wyników badań i aktualnych tendencji w edukacji osób z niepełnosprawnością warto postawić pytanie, czy edukacja włączająca daje szanse na tworzenie lepszych relacji rówieśniczych dla młodzieży z głębszą niepełnosprawnością intelektualną niż w edukacji specjalnej? Stosunkowo duża liczba relacji pozytywnych niepełnych oraz fakt iż aż 15 spośród badanych uczniów nie uczestniczyło w żadnej relacji o przewadze ustosunkowań pozytywnych każe poszukiwać poprawy tej sytuacji. Bliższa analiza pokazuje, że przyczyn powyższego stanu rzeczy należy upatrywać w różnicach funkcjonowania kolegów/koleżanek $\mathrm{w}$ ramach jednej klasy oraz $\mathrm{w}$ trudnościach radzenia sobie przez jednych uczniów z odmiennością i „dziwnymi zachowaniami" innych rówieśników. Czy zatem partner zachowujący się "normalnie", o wyższej sprawności intelektualnej i większych umiejętnościach interpersonalnych wyjdzie naprzeciw potrzebom rówieśnika z głębszą niepełnosprawnością intelektualną? Czy posiadając lepsze możliwości adaptacyjne, sprawny rówieśnik będzie tonował pojawiające się trudności we wzajemnej relacji? Psychologia okresu dojrzewania, zasady atrakcyjności społecznej i wyniki badań każą wątpić w potwierdzenie postawionej hipotezy.

Młodzi ludzie dążą przede wszystkim do kontaktów z osobami, z którymi chcieliby się utożsamiać, co jest dla nich niezmiernie ważne $\mathrm{w}$ procesie kształtowania własnej tożsamości i na drodze 
poszukiwania przyjaciela13. Podobieństwo partnera relacji, wspólna płaszczyzna porozumienia jest tym, co przyciąga młodych ludzi do siebie ${ }^{14}$. O ile młodzież z głębszą niepełnosprawnością intelektualną chętnie nawiązuje relacje ze sprawnymi intelektualnie rówieśnikami, chcąc utożsamiać się z nimi, o tyle dla drugiej strony relacja $\mathrm{z}$ niepełnosprawnym kolegą/koleżanką w żaden sposób nie jest atrakcyjna i pożądana. Potwierdzają tę tendencję wyniki badań wśród młodzieży gimnazjalnej, która przy zgodzie dla obecności ucznia z niepełnosprawnością w klasie, w 70\% wyraziła zdecydowaną niechęć do nawiązania z nim bliższej relacji koleżeńskiej15. Pewną szansą zdają się być tutaj relacje o charakterze opiekuńczym. Wymagają one jednak od młodzieży z normą intelektualną dużej dojrzałości umysłowej i emocjonalnej i nie zaspokajają potrzeby pełnego wzajemnego zrozumienia i znalezienia przyjaciela przez młodzież z niepełnosprawnością intelektualną.

Doniesienia $\mathrm{z}$ praktyki edukacji włączającej ${ }^{16}$ niestety sugerują jej negatywny wpływ na rozwój psychospołeczny uczniów z umiarkowaną niepełnosprawnością intelektualną, a status ucznia w klasie (w przypadku osób z niepełnosprawnością intelektualną jest to status ucznia najsłabszego) zdaje się mocno determinować ich sytuacje w zespole klasowym. Aby dokonać rzetelnej oceny rzeczywistości edukacji inkluzyjnej, należy poddać ją badaniom empirycznym,

${ }^{13}$ H. Bee, Psychologia rozwoju człowieka, Zysk i S-ka, Poznań, 2004; I. Obuchowska I., Adolescencja, [w:] Psychologia rozwoju człowieka. Charakterystyka okresów życia człowieka, red. B. Harwas-Napierała, J. Trempała, PWN, Warszawa, 2005, s. 163-201.

14 Por. Z. Nęcki, Komunikacja międzyludzka, ANTYKWA, Kraków 2000.

${ }_{15}$ M. Rutkowski, Opinie uczniów, rodziców i nauczycieli na temat integracji edukacyjnej, [w:] Dziecko ze specjalnymi potrzebami edukacyjnymi... Przytoczone tu badania są jednymi z wielu, które zostały przeprowadzone w Polsce w ostatnim dwudziestoleciu na temat postaw rówieśników wobec dzieci i młodzieży niepełnosprawnej. Wiele z nich pokazuje najsłabszą sytuację osób z niepełnosprawnością intelektualną spośród innych osób niepełnosprawnych $\mathrm{w}$ relacjach $\mathrm{z}$ rówieśnikami $\mathrm{w}$ normie intelektualnej I. Chrzanowska, Pedagogika specjalna. Od tradycji do wspótczesności. Impuls, Kraków 2015, s. 98-109.

${ }^{16}$ Wspomniane doniesienia płynęły od dyrekcji i nauczycieli placówek specjalnych, do których trafiali uczniowie z głębszą niepełnosprawnością intelektualną po kilku latach edukacji w szkole ogólnodostępnej. 
także w zakresie relacji interpersonalnych uczniów i wspierania ich rozwoju psychospołecznego. Otwiera się zatem kolejny istotny obszar poszukiwań badawczych, których wyniki powinny być ważnymi przesłankami dla podejmowanych decyzji o edukacji osób z niepełnosprawnością intelektualną.

Wracając do wyników przedstawionych badan, warto zauważyć, że wskazują one na pozytywne aspekty edukacji specjalnej, ale także na potrzebę przemyślanych działań, które poprawiłby w jej ramach sytuację społeczną uczniów z głębszą niepełnosprawnością intelektualną. Ważnym zadaniem okazuje się właściwy dobór uczniów do oddziałów szkolnych. Najkorzystniejsze pod względem wspierania pozytywnych relacji rówieśniczych jest łączenie w grupie klasowej uczniów o podobnym poziomie funkcjonowania intelektualnego i poziomie samoobsługi oraz różnej płci. Ocena stopnia niepełnosprawności, umiarkowanego lub znacznego, jest w tym względzie niewystarczająca i wymaga bardziej szczegółowej diagnozy poziomu sprawności intelektualnej uczniów. Ze szczególną uwagą należy potraktować uczniów o najniższych poziomach funkcjonowania intelektualnego oraz przejawiających wyraźne zaburzania zachowania. Ponadto konieczne jest udzielenie pomocy uczniom z umiarkowaną niepełnosprawnością intelektualną $\mathrm{w}$ rozumieniu siebie, swojej niepełnosprawności i niepełnosprawności rówieśników w klasie, aby mogli lepiej kształtować wzajemne kontakty. Organizacja grup zainteresowań opartych na wspólnej aktywności w atrakcyjnej dla uczniów dziedzinie powinna poszerzać zakres alternatyw kontaktów społecznych i sprzyjać nawiązywaniu pozytywnych stosunków rówieśniczych.

\section{Bibliografia}

Adler R.B., Rosenfeld L.B., Proctor II R.F., Relacje interpersonalne, Rebis, Poznań 2006. Bartkowicz Z. Struktura i niektóre uwarunkowania interakcji przejawianych przez upośledzonych umystowo w stopniu umiarkowanym i znacznym, [w:] Optymalizacja interakcji w procesie usprawniania osób $z$ dysfunkcjami fizycznymi i psychicznymi, red. S. Kowalik, J. Kwiek, B. Szychowiak, Wydawnictwo Naukowe UAM, Poznań 1989. 
Bee H., Psychologia rozwoju człowieka, Zysk i S-ka, Poznań 2004.

Bokus B., Proces inicjowania interakcji społecznych przez dzieci 3-5-letnie. Metoda analizy, niektóre wyniki, [w:] Studia z psycholingwistyki ogólnej i rozwojowej, red. I. Kurcz, Zakład Narodowy im. Ossolińskich, Wydawnictwo PAN, Wrocław 1983.

Chrzanowska I., Pedagogika specjalna. Od tradycji do wspótczesności, Oficyna Wydawnicza „Impuls”, Kraków 2015.

Cialdini R., Wywieranie wptywu na ludzi. Teoria i praktyka, GWP, Gdańsk 2011.

Drozdowicz A., Stosunki rówieśnicze młodziė̇y z umiarkowana i znaczną niepełnosprawnościa intelektualna w klasach szkolnictwa specjalnego, niepublikowana praca doktorska, UAM, Poznań 2007.

Fornalik I., Rozwój psychoseksualny młodzieży z głębszą niepetnosprawnościa intelektualna w zależności od środowiska życia, nie publikowana praca doktorska, UAM, Poznań 2002.

Górnicka B., Plany życiowe młodzieży z lekkim upośledzeniem umysłowym, Uniwersytet Opolski, Opole 2004.

Grzegorczykowa R., Wprowadzenie do semantyki językoznawczej, PWN, Warszawa 2002.

Integracja społeczna osób niepetnosprawnych, red. G. Dryżałowska, H. Żuraw, Żak, Warszawa 2004.

Konwencja o prawach osób niepełnosprawnych, Dz.U. z 2012 r., poz. 1169.

Kurcz I., Psychologia języka i komunikacji, Scholar, Warszawa 2000.

Hinde R.A., Stevenson-Hinde J., Związki interpersonalne a rozwój dziecka, [w:] Dziecko $w$ świecie ludzi i przedmiotów, red. A. Brzezińska, G. Lutomski, Zysk S-ka, Poznań 1994.

Maciarz A. Z teorii i badań społecznej integracji dzieci niepetnosprawnych, Impuls, Kraków 1999.

Maciarz A. Integracja edukacyjna w świetle doświadczeń i oczekiwań dzieci niepetnosprawnych, [w:] Dziecko ze specjalnymi potrzebami edukacyjnymi w ekosystemie, red. W. Pilecka, A. Ozga, P. Kurtek, Wydawnictwo AŚ, Kielce 2005.

Nęcki Z., Komunikacja międzyludzka, ANTYKWA, Kraków 2000.

Obuchowska I., Adolescencja, [w:] Psychologia rozwoju człowieka. Charakterystyka okresów życia człowieka, red. B. Harwas-Napierała, J. Trempała, PWN, Warszawa 2005.

Rutkowski M., Opinie uczniów, rodziców i nauczycieli na temat integracji edukacyjnej, [w:] Dziecko ze specjalnymi potrzebami edukacyjnymi w ekosystemie, red. W. Pilecka, A. Ozga, P. Kurtek, Wydawnictwo AŚ, Kielce 2005.

Sikorski J., Pozycja społeczna dziecka niepetnosprawnego w klasie integracyjnej, [w:] O poznawaniu siebie i świata przez dziecko ze specjalnymi potrzebami edukacyjnymi, red. W. Pilecka, K. Bidziński, M. Pietrzkiewicz, Wydawnictwo UHP, Kielce 2008.

Zaborowski Z., Stosunki międzyludzkie, Ossolineum, Wrocław 1976.

Żyta A., Rodzeństwo osób z głębszą niepetnosprawnością intelektualna, Oficyna Wydawnicza „Impuls”, Kraków 2004. 